\title{
Lectotypification of five subspecies names of Hieracium auriculoides and H. brachiatum (Asteraceae) described from the North Caucasus by D.I. Litvinov and K.H. Zahn
}

\author{
Natalia M. SHIYAN ${ }^{1}$, Valeria S. PAVLENKO-BARYSHEVA ${ }^{1}$, Ivan V. TATANOV² \\ ${ }^{1}$ M.G. Kholodny Institute of Botany, National Academy of Sciences of Ukraine \\ 2, Tereshchenkivska Str., Kyiv 01004, Ukraine \\ herbarium_kw@ukr.net \\ valerie.barysheva@gmail.com \\ ${ }^{2}$ V.L. Komarov Botanical Institute, Russian Academy of Sciences \\ 2, Prof. Popova Str., St. Petersburg 197376, Russia \\ tatanov@binran.ru
}

Shiyan N.M., Pavlenko-Barysheva V.S., Tatanov I.V. Lectotypification of five subspecies names of Hieracium auriculoides and $\boldsymbol{H}$. brachiatum (Asteraceae) described from the North Caucasus by D.I. Litvinov and K.H. Zahn. Ukr. Bot. J., 2017, 74(6): 532-538.

Abstract. Five names of subspecies of Hieracium s.l. (Asteraceae) described from the North Caucasus by D.I. Litvinov and K.H. Zahn are lectotypified: Hieracium auriculoides Láng subsp. basileucum Litv. et Zahn, H. auriculoides subsp. sabiniceps Litv. et Zahn (三H. auriculoides subsp. sabinocephalum Litv. et Zahn, nom. illeg.), H. auriculoides subsp. sublasiophorum Litv. et Zahn, $H$. auriculoides subsp. umbelliforme Litv. et Zahn ( $\equiv$ H. auriculoides subsp. subumbelliforme Zahn, nom. illeg.; H. subumbelliforme Üksip), and H. brachiatum Bertero ex DC. subsp. alticaule Litv. et Zahn. For each subspecies, the following data are provided: basionym, main synonyms, information about type localities according to the protologue, lectotype (isolectotypes, syntypes, if applicable) and their herbarium barcodes, and nomenclatural notes. In addition, scanned images of all newly designated lectotypes are presented.

Keywords: Asteraceae, Hieracium, Pilosella, nomenclature, lectotypification, Litvinov, Zahn, North Caucasus

\section{Introduction}

Hieracium s. 1. (including currently recognized segregate genera Hieracium L. and Pilosella Vaill., Asteraceae) is considered among the most taxonomically and nomenclaturally difficult groups of genera because of the processes of intensive interspecific hybridization and apomixis observed in some species groups. According to various estimates, the number of taxonomic units described in this group is more than 15000 (IPNI, http://www.ipni.org/index.html), with about 6000 taxa being considered apomicts (Shaw, Willis, 1985). Therefore, there are some problems with identification of plants of Hieracium and Pilosella because their specific morphological characteristics are often not clearly manifested, or the same or similar characters are sometimes present in representatives of several geographically distant and taxonomically distinct groups. Because of that, for addressing various issues of taxonomy of Hieracium s. 1., comprehensive studies are conducted using anatomical, morphological, populational, genetic, and recently also molecular phylogenetic methods (Sennikov, Illarionova, 2002; Suda, 2007; Zini, 2008; Qurwshi, 2009, etc.).

(C) N.M. SHIYAN, V.S. PAVLENKO-BARYSHEVA, I.V. TATANOV, 2017
Because of the large number of infrageneric and infraspecific entities described within Hieracium s. 1., there is some confusion in delimiting and understanding their taxonomic borders. Therefore, important steps toward resolving taxonomic and nomenclatural problems in this group include proper typification of names applied to various taxa. There are not so many articles about typification of names in Hieracium s. 1. as could be expected (Gubanov, 2002; Sennikov, 2007; Szeląg, 2007, 2011; Tyler, 2007, etc.). Consequently, search for original material and typification of names in Hieracium s. 1. not only provides a clearer picture of particular species, subspecies, varieties, etc., but also serves for better resolution of taxonomy of the group and floristic research. It is also an important basis for solving the problem of understanding the concepts of "species" (agamospecies, microspecies etc.) and "species aggregates" within the group (Manton, 1958; Üksip, 1960; Sennikov, 2003 etc.).

When managing and inventorying the collections of Hieracium s. 1. in the National Herbarium of Ukraine ( $K W-$ Herbarium of the M.G. Kholodny Institute of Botany of the NAS of Ukraine), we studied specimens of exsiccates Herbarium Florae Rossicae (HFR) where some taxa of this genus were published. It has become evident that several names of subspecies in Hieracium s. 1., those described by the German botanist K.H. Zahn 
based on specimens of D.I. Litvinov from the North Caucasus, are still in need of lectotypification. In this article we propose lectotypifications of four names of subspecies of $H$. auriculoides Láng (now accepted as Pilosella $\times$ auriculoides (Láng) P.D. Sell et C. West) and one name of subspecies of $H$. brachiatum Bertero ex DC. (now Pilosella brachiata (Bertero ex DC.) F.W. Schultz et Sch. Bip.).

\section{Materials and methods}

Search for authentic material of the studied subspecies of $H$. auriculoides and $H$. brachiatum was performed directly in the collections of the National Herbarium of Ukraine, $K W$ (Herbaria..., 2011) and other herbarium collections, including the following ones: $G, G H, K F T A$, $L E, L E C B, L W, M W, S, W U$, etc. For this purpose, our search was conducted directly in several collections and in online herbarium databases and other resources, for example, Catalogue des herbiers de Genève $(G)$ : http://www.ville-ge.ch/musinfo/bd/cjb/, The Gray Herbarium $(G H)$ : http://kiki.huh.harvard.edu/, Virtual Herbaria: http://herbarium.univie.ac.at/, JSTOR Global Plants (https://plants.jstor.org), etc.

Names of taxa and their authors are given mainly according to the International Plant Names Index (IPNI, http://www.ipni.org/). Typification was carried out following the rules of the International Code of Nomenclature for algae, fungi, and plants (ICN: McNeill et al., 2012).

The names of taxa are listed alphabetically; for each taxon, the following data are provided: basionym; a short nomenclatural note that include only main synonyms; information about the type (or syntypes) according to protologue; lectotype (isolectotypes, syntypes, as applicable) and their herbarium barcodes (if available); and nomenclatural comments (if necessary). If information about a specimen was taken from online resources, the barcode and web address (URL) are provided.

\section{Results and Discussion}

1. Hieracium auriculoides Láng subsp. basileucum Litv. et Zahn, 1907, Repert. Spec. Nov. Regni Veg. 4: 189; id., 1911, Sched. HFR, VII, Nos. 2001-2400: 20, No. 2052; Zahn, 1923, in Engl. Pflzr. IV. 280, Heft 82: 1521. - Hieracium basileucum (Litv. et Zahn) Üksip, 1960, Фл. СССР, 30: 493.

Type according to protologue: "Prov. Kuban: In pratis pinetisque siccis ad fl. Teberda, $1260 \mathrm{~m}$ ".

Lectotype (Shiyan et al., designated here): "HFR No. 2052. Кубанск[ая] обл. На сухом лугу по p. Теберде, ок. 1260 м. - Caucasus, Prov. Kuban, in pratis siccis ad fl. Teberda. 28.VI 1905. Д. Литвинов", LE 01024063 (Fig. 1).
Isolectotypes: $\quad G \quad 00300084 \quad$ (http://plants.jstor. org/stable/10.5555/al.ap.specimen.g00300084); KFTA $0000451 \quad$ (http://plants.jstor.org/stable/10.5555/ al.ap.specimen.kfta0000451; http://herbarium.univie.ac. at/database/detail.php?ID=313012); $K W 000114909$; $K W \quad 000114910 ; \quad K W$ 000114911; $L E$ 01024065; LE01024066; LE01024068; LE01024069; LECB 0000289 (http://herbarium.univie.ac.at/database/detail. php?ID=503717); LECB 0000290 (http://herbarium. univie.ac.at/database/detail.php?ID $=503718)$; $M W$ s.n. (Gubanov, 2002); S 12-19898 (http://plants. jstor.org/stable/10.5555/al.ap.specimen.s12-19898).

Syntypes: "HFR No. 2052. Кубанск[ая] обл. На сухом лугу по р. Теберде, ок. 1260 м. - Caucasus, Prov. Kuban, in pratis siccis ad fl. Teberda. 01.VII 1905. Д. Литвинов", LE 01024064; LE 01024067.

Note. Zahn (1907) provided no information about the collection date in the protologue of $H$. auriculoides subsp. basileucum. However, another (later) description of the subspecies was published in 1911 in the HFR exsiccata, in volume 7 of that series edited by Litvinov (Litwinow, 1911). In this publication, original material of this taxon was distributed under No. 2052, with two collection dates. Subsequently Zahn provided a note in his monograph on Hieracium in A. Engler's Das Pflanzenreich: "Subsp. 29. basileuciim Litw. et Zahn in Fedde, Rep. III. (1907) 189 et in Sched. Herb. fl. Ross. VII. (1911) 20, exs. n. 2052!" (Zahn, 1923). Under No. 2052 of HFR, Litvinov in 1911 in fact published data on two gatherings of $H$. auriculoides subsp. basileucum, which differ in their collection dates, 28.VI 1905 and 01.VII 1905 (Litwinow, 1911). Because of that, for each specimen of No. 2051, one of these two dates was underlined manually on the label, indicating the collection date of that particular specimen (see Fig. 1). More than half of original specimens of $H$. auriculoides subsp. basileucum that we studied were collected on 28.VI 1905.

We designate here the specimen $L E 01024063$ (Fig. 1) as the lectotype of $H$. auriculoides subsp. basileucum; it was collected by Litvinov on 28.VI 1905. This specimen has a typographically printed HFR label with the taxon name, a detailed Latin description by Zahn, the location and date of collection. The remaining original specimens from $L E$ collected by Litvinov on 28.VI 1905 are not published exsiccates; they have handwritten labels. Identification of plants (as "Hieracium panonicum N.P. subsp. basileuciim Litw. et Zahn") and the actual text in these labels has some differences in ink color, indicating some time lag between the collection of this material and its processing.

2. Hieracium auriculoides Láng subsp. sabiniceps Litv. et Zahn, 1907, Repert. Spec. Nov. Regni Veg. 4: 190, "sabinocephalum in litt."; Zahn, 1923, in Engl. Pflzr. IV. 280, Heft 82: 1519. - H. auriculoides Láng subsp. sabinocephalum Litv. et Zahn, 1911, Sched. HFR, VII, Nos. 2001-2400: 22, No. 2057, nom. illeg. H. sabiniceps (Litv. et Zahn) Üksip, 1960, Фл. СССР, 30: 499.

Type according to protologue: "Prov. Kuban: Ad fontes fl. Teberda, $2340 \mathrm{~m}$ ". 
Lectotype (Shiyan et al., designated here): "HFR No. 2057. Кубанск[ая] обл. Истоки р. Теберды, ок. 2270 м., по каменистому склону в подальпийской области. - Prov. Kuban (Caucasus), ad fontes fl. Teberda, in saxosis subalpinis. 12.VII 1905. Собр. Д. Литвинов", LE 01026015 (Fig. 2).

Isolectotypes: $G H \quad 00009177$ (http://plants.jstor. org/stable/10.5555/al.ap.specimen.gh00009177); $K W$ 000114946; KW 000114947; LE 01026016; LECB 0000292 (http://herbarium.univie.ac.at/database/detail. php?ID=558114); $M W$ s.n. (Gubanov, 2002); $S$ 1219895 (http://plants.jstor.org/stable/10.5555/al.ap. specimen.s12-19895).

Note. It is likely that the authors used in their correspondence two alternative names before validating this subspecies. When describing new taxa in 1907, Zahn used the name $H$. auriculoides Láng subsp. sabiniceps Litv. et Zahn, but also noted that this subspecies was named (in his letter) as "sabinocephalum" (Zahn, 1907). The latter epithet was used for original material published in HFR under No. 2057 (Litwinow, 1911), but the protologue erroneously reported other values of the altitude above sea level than those indicated on Litvinov's specimens. Therefore, to correct errors in citing the type, in 1923 Zahn reported that taxon as "Subsp. 20. sabiniceps Litw. et Zahn in Fedde, Rep. III. (1907) 190. subsp. sabinocephalum Litv. et Zahn in Sched. Herb. fl. Ross. VII. (1911) 22", and cited the type as "Kaukasus: An den Quellen der Teberda, 2270 m, in der Provinz Kuban!" (Zahn, 1923). We designate here as the lectotype of $H$. auriculoides subsp. sabiniceps one of duplicates collected by Litvinov ( $L E$ 01026015) and published in HRF (as "sabinocephalum") under No. 2057.

3. Hieracium auriculoides Láng subsp. sublasiophorum Litv. et Zahn, 1907, Repert. Spec. Nov. Regni Veg. 4: 188; id. 1911, Sched. HFR, VII, Nos. 2001-2400: 23, No. 2058; Zahn, 1923, in Engl. Pflzr. IV. 280, Heft 82: 1522. - Hieracium sublasiophorum (Litv. et Zahn) Üksip, 1960, Фл. СССР, 30: 496.

Type according to protologue: "Prov. Kuban: Ad fonts fl. Teberda, $2300 \mathrm{~m}$.

Lectotype (Shiyan et al., designated here): "HRF No. 2058. Кубанок[ая] обл. Истоки р. Теберды, ок. 2300 м., по каменистому склону в подальпийской области.- Prov. Kuban (Caucasus), in subalpinis ad fonts fl. Teberda. 12.VII 1905. Д. Литвинов", LE 01026018 (Fig. 3).

Isolectotypes: $G H \quad 00009178$ (http://plants.jstor. org/stable/10.5555/al.ap.specimen.gh00009178); $K W \quad 000124249 ; \quad K W \quad 000124250 ; \quad L E \quad 01026017$; LE 01026019; $M W$ s.n. (Gubanov, 2002); S 12-19896 (http://plants.jstor.org/stable/10.5555/al.ap.specimen. s12-19896).

Note. A duplicate description of $H$. auriculoides Láng subsp. sublasiophorum Litv. et Zahn was provided in HFR under No. 2058 (Litwinow, 1911). Texts of descriptions in
"Schedae ..." (Litwinow, 1911) and on labels of specimens (Fig. 3) are completely identical to the protologue (Zahn, 1907). One of Litvinov's duplicates published in HFR under No. 2064 and now deposited in $L E$ is designated here as the lectotype ( $L E$ 01026018).

4. Hieracium auriculoides Láng subsp. umbelliforme Litv. et Zahn, 1911, Sched. HFR, VII, Nos. 2001 - 2400: 24, No. 2061b. - Hieracium auriculoides Láng subsp. subumbelliforme Zahn, 1923, in Engler, Pflanzr. IV. 280, Heft 82: 1517, nom. illeg. - Hieracium subumbelliforme Üksip, 1960, Фл. СССР, 30: 501, non Jord. ex Boreau (1857).

Type according to protologue: "[HFR] No. 2061a. Черноморская губ. По опушке леса бл. ст. Михайловской - Prov. Czernomorskaja (Caucasus), ad nemorum margines pr. stat. Michailowskaja. 08.VI 1907. Собр. Д. Литвинов; No. $2061 \mathrm{~b}$. Черноморск[ая] губ. По приморскому лугу в долине p. Адербы бл. Геленджика - Prov. Czernomorskaja (Caucasus). In pratis maritimis ad ostium fl. Aderba pr. Gelendshik. 31.V 1907. Собр. Д. Литвинов".

Lectotype (Shiyan et al., designated here): "HFR No. 2061b. Черноморск[ая] губ. По приморскому лугу в долине р. Адербы бл. Геленджика. - Prov. Czernomorskaja (Caucasus). In partis maritimis ad ostium fl. Aderba pr. Gelendshik. 31.V 1907. Собр. Д. Литвинов", LE 01026020 (Fig. 4).

Isolectotypes: $\quad G H \quad 00009179 \quad$ (http://kiki. huh.harvard.edu/databases/specimen_search. php? mode $=$ details\&id $=133416) ; \quad K W \quad 000124247$; $K W \quad 000124248 ; \quad L E \quad 01026021 ; \quad L E C B \quad 0000294$ (http://herbarium.univie.ac.at/database/detail. php? ID=558116).

Syntype: "HFR No 2061a. Черноморская губ. По опушке леса бл. ст. Михайловской. - Prov. Czernomorskaja (Caucasus), ad nemorum margines pr. stat. Michailowskaja. 03.VI 1907. Собр. Д. Литвинов", S 12-19897 (http://plants.jstor.org/stable/ 10.5555/ al.ap.specimen.s12-19897).

Note. Some confusion occurred with the interpretation of correct names for this taxon at the species and subspecies ranks. It was validly described as a subspecies, $H$. auriculoides Láng subsp. umbelliforme Litv. et Zahn (Litwinow, 1911: 24), but in 1923 K.H. Zahn (in A. Engler's Das Pflanzenreich) accepted a new name for this subspecies, $H$. auriculoides subsp. subumbelliforme Zahn, with subsp. umbelliforme Litv. et Zahn cited as its synonym, and indicated two syntypes published in HRF under No. 2061a, b (Zahn, 1923: 1517). Evidently, Zahn (1.c.) considered $H$. auriculoides subsp. umbelliforme Litv. et Zahn to be a later homonym of $H$. umbelliforme Jord. ex Boreau (Boreau, 1857: 389). However, according to Art. 11.2 of ICN (McNeill et al., 2012), a name has no priority outside the rank in which it is published. Consequently, the name $H$. auriculoides subsp. subumbelliforme Zahn is illegitimate, being a superfluous substitute for $H$. auriculoides 

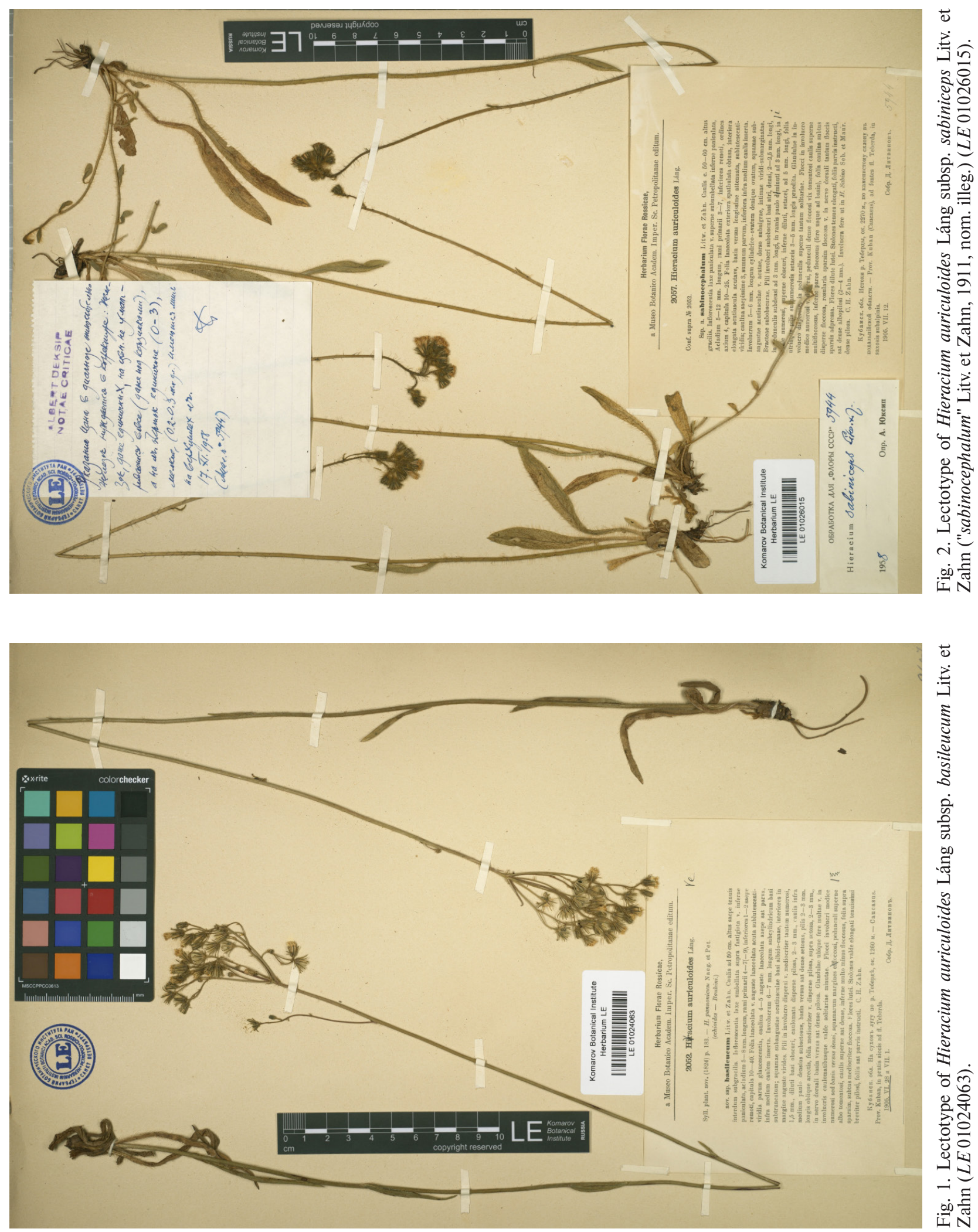

Укр. бот. журн., 2017, 74(6) 


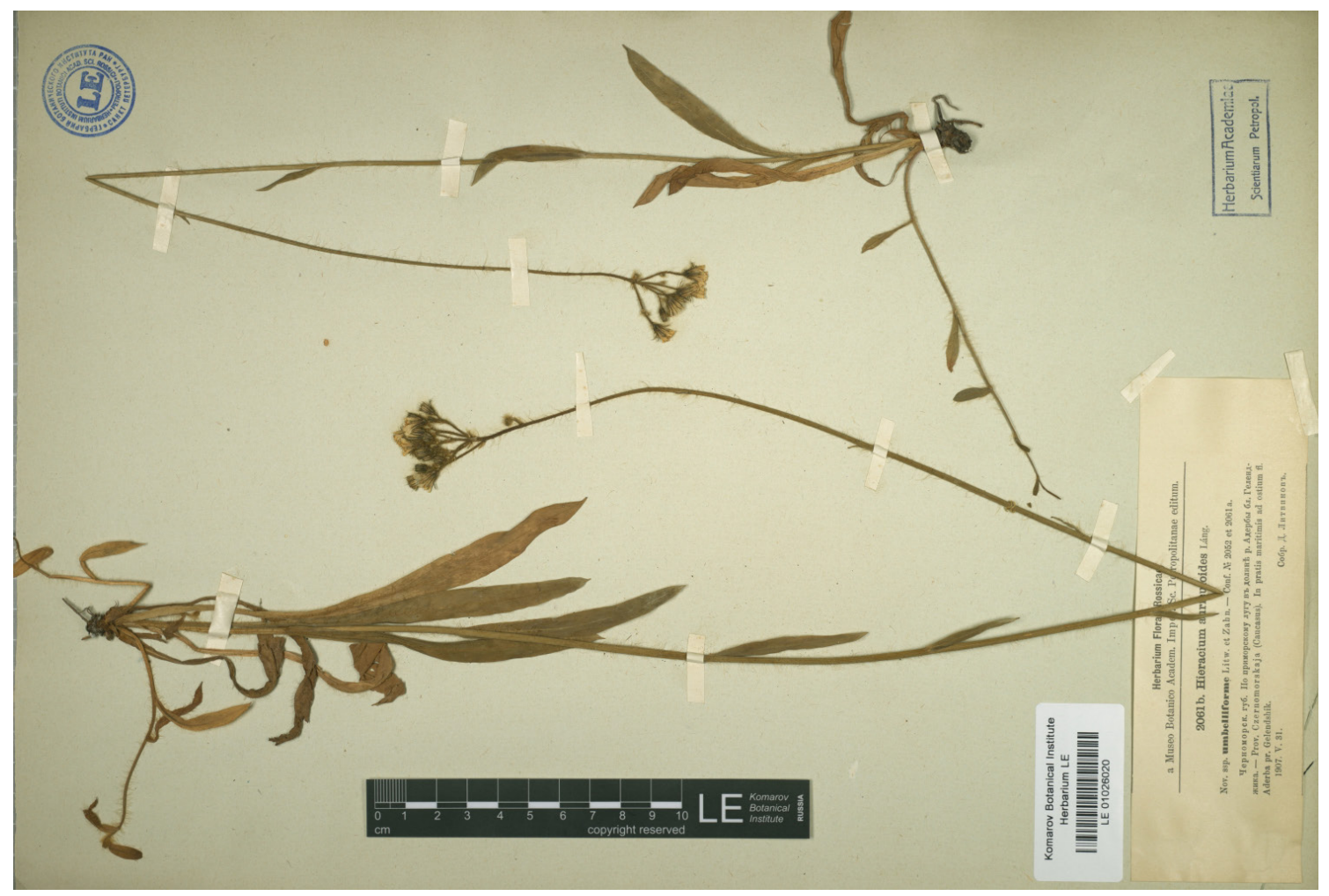

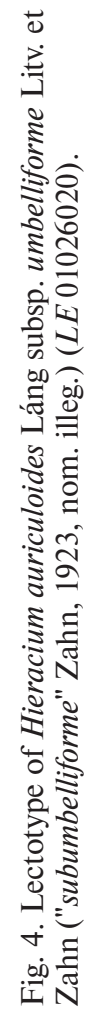

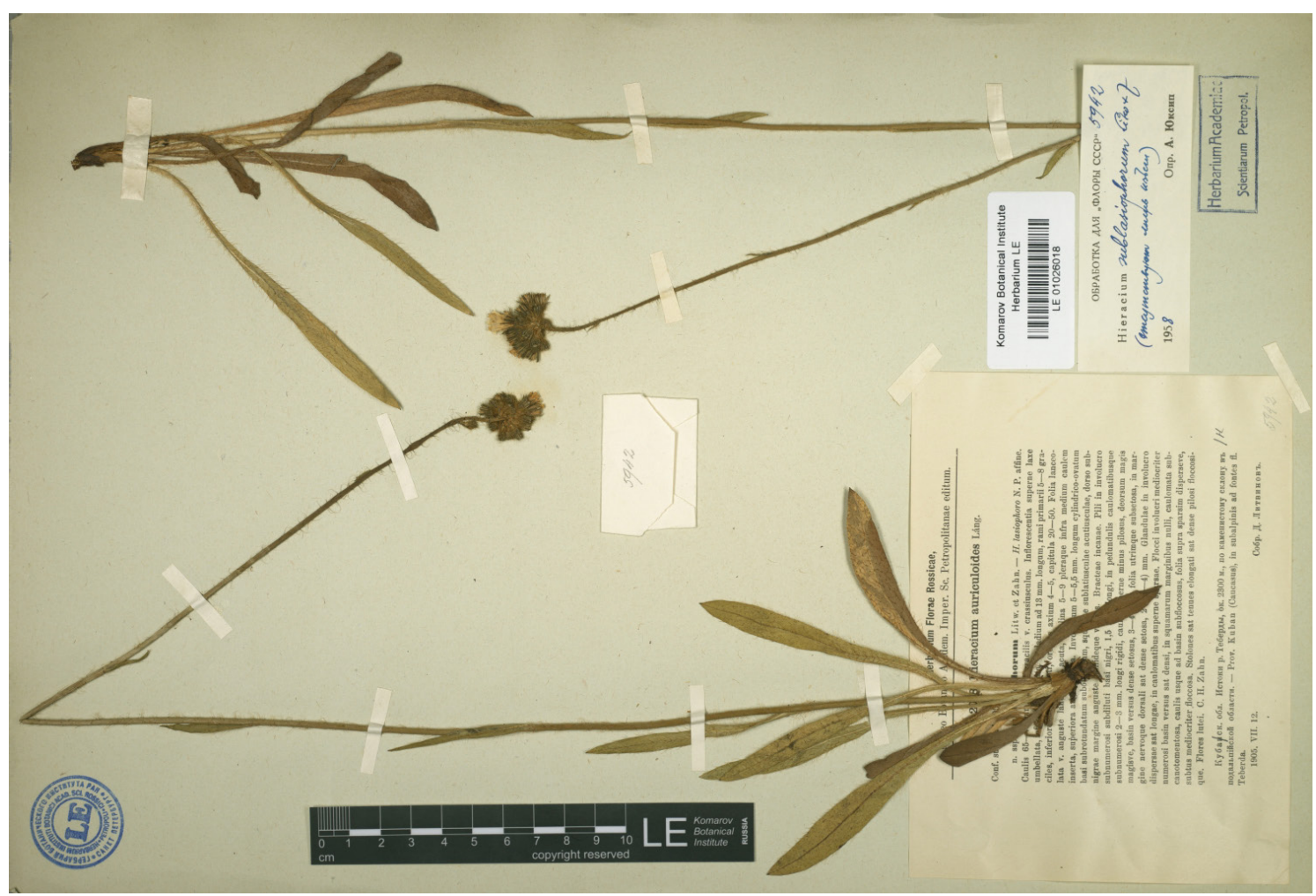

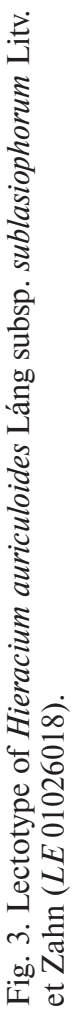




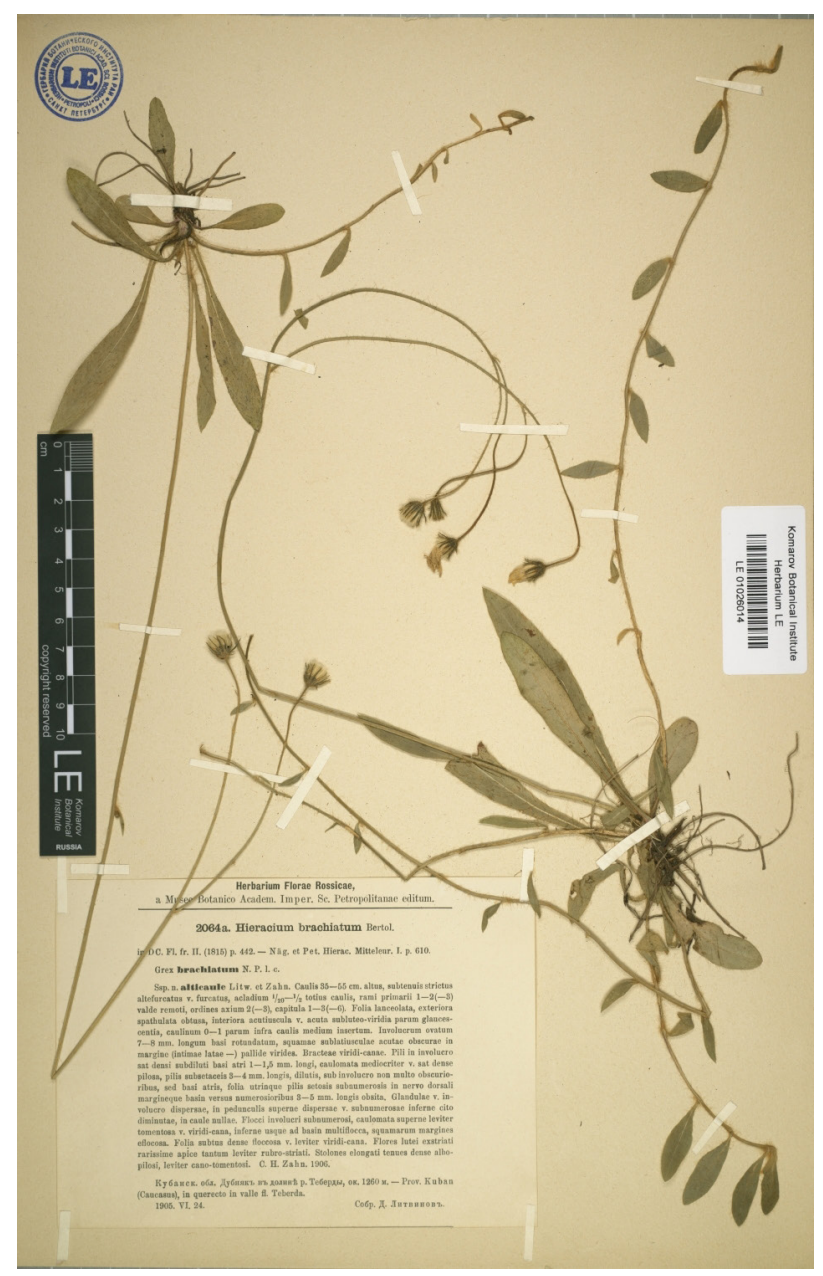

Fig. 5. Lectotype of Hieracium brachiatum Bertol. ex DC. subsp. alticaule Litv. et Zahn (LE 01026014).

subsp. umbelliforme Litv. et Zahn. Üksip (1960) accepted that taxon as " $H$. subumbelliforme Zahn" and mentioned in its synonymy the non-existing binomial " $H$. umbelliforme Litw. et Zahn $<\ldots>$ non Jord. nec Vukot." By doing that, he validated a new name (nomen novum) that should be cited as $H$. subumbelliforme Üksip (not as a new combination "H. subumbelliforme (Zahn) Üksip").

Considering the studied original materials of $H$. auriculoides subsp. umbelliforme, we designate here as the lectotype one of duplicates collected by Litvinov ( $L E$ 01026020), the one which was published in HRF under No. 2061b.

5. Hieracium brachiatum Bertol. ex DC. subsp. alticaule Litv. et Zahn, 1907, Repert. Spec. Nov. Regni Veg. 4: 184; id., 1911, Sched. HFR, VII, Nos. 20012400: 25, No. 2064a; Zahn, 1923, in Engl. Pflzr. IV. 280, Heft 82: 1457. - Hieracium alticaule (Litv. et Zahn) Üksip, 1960, Фл. СССР, 30: 536.

Type according to protologue: "Prov. Kuban: In quercetis ad. fl. Teberda $1260 \mathrm{~m}$. - In silvis m. Shelesnaja pr. Shelesnovodsk".
Lectotype (Shiyan et al., designated here): "HFR No. 2064a. Кубанск[ая] обл. Дубняк в долине p. Теберды, ок. 1260 м. - Prov. Kuban (Caucasus), in querceto in valle fl. Teberda. 24.VI 1905. Собp. Д. Литвинов", LE 01026014 (Fig. 5).

Isolectotypes: $G 00300141$ (http://www.ville-ge. $\mathrm{ch} / \mathrm{musinfo} / \mathrm{bd} / \mathrm{cjb} / \mathrm{chg} /$ adetail.php? $\mathrm{id}=221207)$; GH 00009102 (http://kiki.huh.harvard.edu/databases/ specimen search.php? mode $=$ details \&id $=135567)$; $K W$ 000114905; $K W$ 000114906; LE 01026012; LE 01026013; LECB 0000299 (http://herbarium.univie. ac.at/database/detail.php?ID=558124); $L E C B 0000301$ (http://herbarium.univie.ac.at/database/detail. php?ID=558125), $M W$ s.n. (Gubanov, 2002); $S$ 12-20577 (http://plants.jstor.org/stable/10.5555/al.ap.specimen. s12-20577); $W U 0086551$ (http://herbarium.univie. ac.at/database/detail.php?ID=982135).

Note. A duplicate description of $H$. brachiatum Bertol. ex DC. subsp. alticaule Litv. et Zahn was made in 1911 in HRF, where original material of this taxon was listed under No. 2064a (Litwinow, 1911). Texts of the description in "Schedae..." (Litwinow, 1911) and on labels of specimens (Fig. 5) are identical with the text in the protologue (Zhahn, 1907). We designate here as the lectotype one of duplicates collected by Litvinov ( $L E$ 01026014) and published in HRF under No. 2064a, which is now deposited in LE; the corresponding locality was mentioned in the protologue (Zahn, 1923). It should be noted that Litvinov published under No. 2064b also specimens of the same taxon from another locality.

\section{Acknowledgments}

The authors are grateful to Sergei L. Mosyakin for his useful comments on nomenclature and to Alisa $V$. Shumilova $(K W$, National Herbarium of Ukraine, M.G. Kholodny Institute of Botany, Kiev, Ukraine) for her assistance with the herbarium material.

\section{REFERENCES}

Boreau P.A. Flore du Centre de la France et du Bassin de la Loire ou description des Plantes, ed. 3, Paris: Librairie Encyclopédique de Roret, 1857, vol. 2, 772 pp.

Bräutigam S., Greuter W. A new treatment of Pilosella for the Euro-Mediterranean flora. Willdenowia, 2007, 37(1): $123-137$.

Gubanov I.A. Katalog tipovyh obraztsov sosudistykh rasteniy Herbariia Moskovskoho universiteta (MW), Moscow, 2002, 213 рр. [Губанов И.А. Каталог типовых образцов сосудистых растений Гербария Московского университета (MW), M., 2002, 213 c.].

Herbaria of Ukraine. Index Herbariorum Ucrainicum. Ed. N.M. Shiyan, Kyiv: Alterpress, 2011, 442 pp. [Гербарії Украӥни. Index Herbariorum Ucrainicum. Ред. Н.М. Шиян, Київ: Альтерпрес, 2011, 442 с.].

Litwinow D.I. Schedae ad Herbarium Florae Rossicae, a Museo Botanico Academiae Imperialis Scientiarum Petropolitanae editum, St. Petersburg, 1911, vol. 4, (Nos. 2001-2040), 164 рр. [Литвинов Д.И. Список растений Гербария Русской Флоры, издаваемого Ботаническим 
Музеем Императорской Академии Наук, СПб, 1911, т. 7, (№№ 2001-2040), 164 c.].

Manton I. The concept of the aggregate species. Systematics of Today, 1958: 104-112.

McNeill J., Barrie F.R., Buck W.R., Demoulin V., Greuter W., Hawksworth D.L., Herendeen P.S., Marhold K., Prado J., Prud'homme van Reine W.F., Smith J.F., Wiersema J.H., Turland N.J. International Code of Nomenclature for algae, fungi and plants (Melbourne Code): Adopted by the Eighteenth International Botanical Congress, Melbourne, Australia, July 2011, Ruggell: Koeltz Sci. Books, 2012, 140 pp.

Qureshi S.J., Arshad K.M., Rashid A., Ahmad M., Zafar M. Morphological, palynological, and anatomical investigations Hieracium L. (Lactuceae, Asteraceae) in Pakistan, Métodos en Ecología y Sistemática, 2009, 4(3): 1-22.

Sennikov A.N. A new typification of Hieracium umbellatum (Asteraceae). Nord. J. Bot., 2007, 25(1): 99-103.

Sennikov A.N., Illarionova I.D. Carpological studies in Asteraceae-Cichorieae, Subtribe Hieraciinae. Komarovia, 2002, 2: 97-123.

Sennikov A.N. Turczaninowia, 2003, 6(2): 16-41. [Сенников А.Н. Таксономическая концепция в роде Hieracium L. s. 1. (Asteraceae). Turczaninowia, 2003, 6(2): 16-41].

Shaw H.K.A., Willis J.C. A Dictionary of Flowering Plants and Ferns. $8^{\text {th }}$ edition. Cambridge: Cambridge Univ. Press, 1985,1245 pp.

Suda J., Krahulcová A., Trávniček P., Rosenbaumová R., Peckert T., Krahulec F. Genome size variation and species relationships in Hieracium subgenus Pilosella (Asteraceae) as inferred by flow cytometry. Ann. Bot., 2007, 100(6): 1323-1335.

Szelag Z. Typification of the Hieracium (Asteraceae) names described by E. Wołoszczak from the Eastern Carpathians. Pol. Bot. J., 2007, 52(2): 99-118.

Szelagg Z. Hieracia balcanica VI. Typification of Hieracium pavichii (Asteraceae). Pol. Bot. J., 2011, 56(1): P. 51-54.

Tyler T. Lectotypification of names of Hieracium sect. Hieracium and sect. Vulgata based on material from southern Sweden. Compos. Newsletter, 2006, 44(1): 74-93.

Üksip A.Ya. Hieracium. In: Flora of the USSR. Eds B.K. Shishkin, E.G. Bobrov, Moscow; Leningrad: Izd-vo Acad. Sci. USSR, 1960, vol. 30, 732 pp. [Юксип А.Я. Hieracium. В кн.: Флора СССР. Ред. Б.К. Шишкин, Е.Г. Бобров, М.; Л.: Изд-во АН CCCP, 1960, т. 30, 732 c.].

Zahn K.H. Hieracia Caucasica nova, a D. Litwinow, Petropolitano, annis 1905 et 1906 in Caucaso boreali lecta. Repert. spec. nov. regni veget., 1907, 4: 179-194.

Zahn K.H. Compositae - Hieracium. Sect. XL. PilosellinaSect. XLVIII. Praealtina. In: Das Pflanzenreich. Regni Vegetabilis Conspectus. IV, 280. Ed. A. Engler, 1923, Heft 82, 1705 pp.

Zini E., Komjanc M. Identification of microsatellite markers in Hieracium pilosella L. Conserv. Genet., 2008, 9(2): 487-489.

Recommended for publication by G.V. Boiko
Шиян Н.М., ${ }^{1}$ Павленко-Баришева В.С. ${ }^{1}$, Татанов I.В. ${ }^{2}$

Лектотипіфікація п'яти назв підвидів Hieracium auriculoides та $H$. brachiatum (Asteraceae), описаних 3 Північного Кавказу Д.І. Литвиновим та К.Г. Цаном. Укр. бот. журн., 2017, 74(6): 532-538.

${ }^{1}$ Інститут ботаніки ім. М.Г. Холодного НАН України вул. Терещенківська, 2, Київ 01004, Україна

${ }^{2}$ Ботанічний інститут ім. В.Л. Комарова РАН вул. проф. Попова, 2, Санкт-Петербург 197376, Росія

Лектотипіфіковано назви п'яти підвидів Hieracium s.l. (Asteraceae), описаних Д.І. Литвиновим та К.Г. Цаном з Північного Кавказу: Hieracium auriculoides Láng subsp. basileucum Litv. et Zahn, H. auriculoides subsp. sabiniceps Litv. et Zahn ( $\equiv H$. auriculoides subsp. sabinocephalum Litv. et Zahn, nom. illeg.), H. auriculoides subsp. sublasiophorum Litv. et Zahn, H. auriculoides subsp. umbelliforme Litv. et Zahn (三H. auriculoides subsp. subumbelliforme Zahn, nom. illeg.; H. subumbelliforme Üksip) i $H$. brachiatum Bertero ex DC. subsp. alticaule Litv. et Zahn. Для кожного підвиду наведені: базионім, основні синоніми, інформація про тип за протологом, лектотип, ізолектотип, синтип(и) та їхні баркод(и) відповідного Гербарію; подаються номенклатурні нотатки. Подані зображення (скани) усіх п'яти лектотипів, зазначених у статті.

Ключові слова: Asteraceae, Hieracium, Pilosella, номенклатура, лектотипіфікація, Литвинов, Zahn, Північний Кавказ

Шиян Н.Н. ${ }^{1}$, Павленко-Барышева В.С. ${ }^{1}$, Татанов И.В. ${ }^{2}$

Лектотипификация пяти названий подвидов Hieracium auriculoides и H. brachiatum (Asteraceae), описанных с Северного Кавказа Д.И. Литвиновым и К.Г. Цаном. Укр. бот. журн., 2017, 74(6): 532-538.

${ }^{1}$ Институт ботаники им. Н.Г. Холодного НАН Украины ул. Терещенковская, 2, Киев 01004, Украина

${ }^{2}$ Ботанический институт им. В.Л. Комарова РАН ул. проф. Попова, 2, Санкт-Петербург 197376, Россия

Лектотипифицированны названия пяти подвидов Hieracium s.l. (Asteraceae), описанных Д.И. Литвиновым и К.Г. Цаном с Северного Кавказа: Hieracium auriculoides Láng subsp. basileucum Litv. et Zahn, $H$. auriculoides subsp. sabiniceps Litv. et Zahn ( $\equiv H$. auriculoides subsp. sabinocephalum Litv. et Zahn, nom. illeg.), H. auriculoides subsp. sublasiophorum Litv. et Zahn, $H$. auriculoides subsp. umbelliforme Litv. et Zahn ( $\equiv H$. auriculoides subsp. subumbelliforme Zahn, nom. illeg.; H. subumbelliforme Üksip) и $H$. brachiatum Bertero ex DC. subsp. alticaule Litv. et Zahn. Для каждого подвида указаны: базионим, основные синонимы, информация о типе по протологу, лектотип, изолектотип, синтип(ы) и их баркод(ы) в соответствующем Гербарии; приведены номенклатурные примечания. Даны изображения (сканы) всех пяти лектотипов, обозначенных в статье.

Ключевые слова: Asteraceae, Hieracium, Pilosella,номенклатура, лектотипификация, Литвинов, Zahn, Северный Кавказ 